\title{
Evaluation of Possible First Trimester Prenatal Diagnosis in Lysosomal Diseases by Trophoblast Biopsy
}

\author{
L. POENARU, L. KAPlan, J. DUMEZ, AND J. C. DREYFUS \\ Université Paris V, C.H.U., Cochin (INSERM U.129), 75014 Paris, France
}

\section{Summary}

The detection of enzymatic deficiency in cultured amniotic cells from second trimester pregnancies is presently used for prenatal diagnosis of lysosomal diseases. The possibility of obtaining and processing trophoblast tissue at 8-10 weeks of gestation would permit first trimester prenatal diagnosis. Using trophoblast tissue samples from normal fetuses before voluntary abortion and from placenta after therapeutic abortions of fetuses affected by several lysosomal diseases, we conclude that early diagnosis of lysosomal disorders would be possible.

Antenatal diagnosis of lysosomal diseases is currently based on enzymatic deficiency detection in cultured amniotic cells from second trimester pregnancies $(1,4,12,13,18)$. The major disadvantage of this approach is that amniocentesis cannot be performed efficiently before the 16 th-18th week of gestation and a further 2-4 weeks are necessary while cells are cultured. Thus, when a homozygous fetus is diagnosed, abortion is undesirably late.

Recently, innovative procedures in obtaining and processing trophoblast tissues for first trimester prenatal diagnosis have been reported $(2,6,7,9,14)$. Trophoblast cells are derivatives of the zygote which can be obtained by chorion biopsy without penetration of the amniotic sac (6).

The aim of this study was to evaluate the possibility of first trimester prenatal diagnosis in lysosomal diseases by comparing trophoblast biopsy samples from normal fetuses at $8-10$ weeks of gestation with fetal trophoblasts isolated from placenta coming from four therapeutic abortions of fetuses affected by glycogenosis type II, $\mathrm{GM}_{2}$-gangliosidosis type Tay-Sachs (B), GM $\mathrm{G}_{2}$ gangliosidosis type Sandhoff (o), and metachromatic leukodystrophy.

\section{MATERIALS AND METHODS}

Trophoblast biopsy $\left(3-6 \mathrm{~mm}^{3}\right)$ was performed at 8 to 10 weeks of pregnancy immediately before voluntary abortion. Specimens were obtained by transcervical biopsy without dilatation under ultrasonic control (5). Tissue was immediately collected in sterile physiological solution at $4^{\circ} \mathrm{C}$ and dissected and cleaned from maternal cells under phase contrast microscopy. Specimens of tertiary chorionic villi came from placenta obtained after therapeutic abortion of affected fetuses. These placentas had been conserved at $-20^{\circ} \mathrm{C}$ for over 2 months before dissection. Tro-

Received December 1, 1983; accepted March 12, 1984

Correspondence may be addressed to L. Poenaru, Institut de Pathologie et Biologie Cellulaires et Moléculaires, 24 rue du Fg. St. Jacques, 75674 Paris Cedex 14. France.

This work was supported by a grant from the Institut National de la Santé et de la Recherche Médicale. phoblast samples after dissection $(8-30 \mathrm{mg})$ were kept at $-20^{\circ} \mathrm{C}$ or immediately tested. They were extracted in a microhomogenizer adapted to Eppendorf tubes, with 5 to 10 volumes of water containing $0.1 \%$ Triton X-100. The homogenates were frozen and thawed three times and then centrifuged at $15000 \times g$ for $10 \mathrm{~min}$ and the supernatant immediately was submitted to assay or to electrophoresis.

Enzymatic activity was determined by fluorimetric and colorimetric techniques as described previously $(3,4)$. The general technique involved incubation of $1 \mathrm{mM}$ each of 4-methylumbelliferyl, $p$-nitrocatechol, or $p$-nitrophenyl derivatives with 10 , 20 , or $50 \mu$ l of placenta extract at $37^{\circ} \mathrm{C}$ for 10 to $60 \mathrm{~min}$ according to the enzyme. The reaction was stopped by addition of $1 \mathrm{M}$

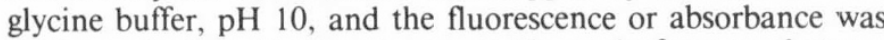
read on a Aminco fluorimeter or on a Eppendorf spectrophotometer. Protein was assayed according to the Lowry method.

Electrophoresis was run on cellulose acetate as described (16) in potassium phosphate buffer, $\mathrm{pH} 6.5$, for hexosaminidase and in veronal-acetic acid buffer $\mathrm{pH} 7.3$ for arylsulfatases. The staining substrates were 4-methylumbelliferyl derivatives. Fluorescent spots were photographed with a Polaroid UV camera. Informed consent was obtained in all cases.

\section{RESULTS}

Table 1 shows the mean value and range of lysosomal enzyme activity in normal trophoblast biopsy extract compared with normal cultured amniotic cells. After extraction, the supernatant used for enzymatic tests contained $1.4-8 \mathrm{mg}$ protein $/ \mathrm{ml}$. Activity levels in trophoblasts were similar to those of cultured amniotic cells for $\alpha$-galactosidase, $\beta$-galactosidase, $\beta$-glucuronidase, and $\alpha$ fucosidase; activity levels were from 5 to 10 times higher for acid $\alpha$-glucosidase, $\beta$-glucosidase, $\beta$-glucuronidase, and $\alpha$-fucosidase. In contrast, trophoblast $\alpha$-iduronidase and neuraminidase activity was very low.

Table 2 shows enzymatic levels in pathological placenta compared to controls. Specific enzymatic deficiency is detectable by assay in trophoblast acid $\alpha$-glucosidase (Pompe's disease), arylsulfatase A (metachromatic leukodystrophy), and total hexosaminidase (Sandhoff disease). As expected, hexosaminidase A deficiency is not detectable by simple assay in Tay-Sachs disease trophoblasts. As in amniotic cells and in other tissues, hexosaminidase A deficiency is masked by an increase in hexosaminidase B. In the case of Tay-Sachs disease, electrophoresis enables a diagnosis to be made.

Figure 1 represents the electrophoretic pattern of hexosaminidase from normal, Sandhoff disease, and Tay-Sachs disease trophoblasts. The pattern is classical for every sample. The absence of hexosaminidase A associated with an increased hexosaminidase B could be observed for Tay-Sachs disease (lane 3). In Sandhoff disease (lane 2), the presence of hexosaminidase S 
is usual but in our trophoblast sample there were also traces of hexosaminidase A. The possible explanation is contamination with maternal enzyme during the 3-month conservation at $-20^{\circ} \mathrm{C}$.

The electrophoretic pattern of arylsulfatases is presented in Figure 2. Lane 1 corresponds to metachromatic leukodystrophy trophoblast compared to control (lanes 2 and 3). Arylsulfatase A deficiency in this case is complete while arylsulfatase B is present at a high level.

\section{DISCUSSION}

Prenatal diagnosis of lysosomal disease during the second trimester of pregnancy is now the current method of preventing these very severe disorders. The major disadvantage of this approach is late pregnancy termination (about 20 weeks). The possibility of trophoblast biopsy opens up new perspectives in

Table 1. Lysosomal hydrolase activity*

\begin{tabular}{|c|c|c|}
\hline & $\begin{array}{c}\text { Trophoblast } \\
\text { (sample 20) } \\
\text { (nmol/mg } \\
\text { protein } / \mathrm{h}\end{array}$ & $\begin{array}{l}\text { Amniotic cells } \\
\text { (sample 100) } \\
\text { (nmol/mg } \\
\text { protein/h) }\end{array}$ \\
\hline$\alpha$-Glucosidase, $\mathrm{pH} 4$ & $\begin{array}{c}325 \\
125-620\end{array}$ & $\begin{array}{c}41 \\
24-71\end{array}$ \\
\hline$\alpha$-Glucosidase, $\mathrm{pH} 6.5$ & $\begin{array}{c}244 \\
120-560\end{array}$ & \\
\hline$\beta$-Glucosidase & $\begin{array}{c}306 \\
100-550\end{array}$ & $\begin{array}{r}24.4 \\
15-62\end{array}$ \\
\hline$\alpha$-Galactosidase & $\begin{array}{r}40.5 \\
14-84\end{array}$ & $\begin{array}{r}46.5 \\
18-75\end{array}$ \\
\hline$\alpha$-Galactosidase & $\begin{array}{c}515 \\
181-800\end{array}$ & $\begin{array}{c}712 \\
214-985\end{array}$ \\
\hline$\alpha$-Mannosidase & $\begin{array}{l}183 \\
97-500\end{array}$ & $\begin{array}{c}133 \\
87-384\end{array}$ \\
\hline$\beta$-Glucuronidase & $\begin{array}{c}110 \\
34-215\end{array}$ & $\begin{array}{c}28.9 \\
15-53\end{array}$ \\
\hline$\beta$-Hexosaminidase & $\begin{array}{c}3328 \\
1200-6650\end{array}$ & $\begin{array}{l}3200 \\
940-4200\end{array}$ \\
\hline$\alpha$-Glucosaminidase & $\begin{array}{r}4.4 \\
3-6.4\end{array}$ & $\begin{array}{r}4.7 \\
1.2-6.3\end{array}$ \\
\hline$\alpha$-Fucosidase & $\begin{array}{c}997 \\
400-1940\end{array}$ & $\begin{array}{c}102 \\
79-210\end{array}$ \\
\hline Arylsulfatase A & $\begin{array}{c}72 \\
42-134\end{array}$ & $\begin{array}{c}134.5 \\
44-251\end{array}$ \\
\hline Arylsulfatase B & $\begin{array}{c}87 \\
60-154\end{array}$ & $\begin{array}{c}128 \\
32-340\end{array}$ \\
\hline Iduronidase & $\begin{array}{r}2.4 \\
1.8-5.2\end{array}$ & $\begin{array}{c}62.7 \\
21-179\end{array}$ \\
\hline Protein $(\mathrm{mg} / \mathrm{ml})$ & $\begin{array}{r}4.1 \\
1.4-8.6\end{array}$ & $0.2-4.2^{2.13}$ \\
\hline
\end{tabular}

* Values are means and ranges.

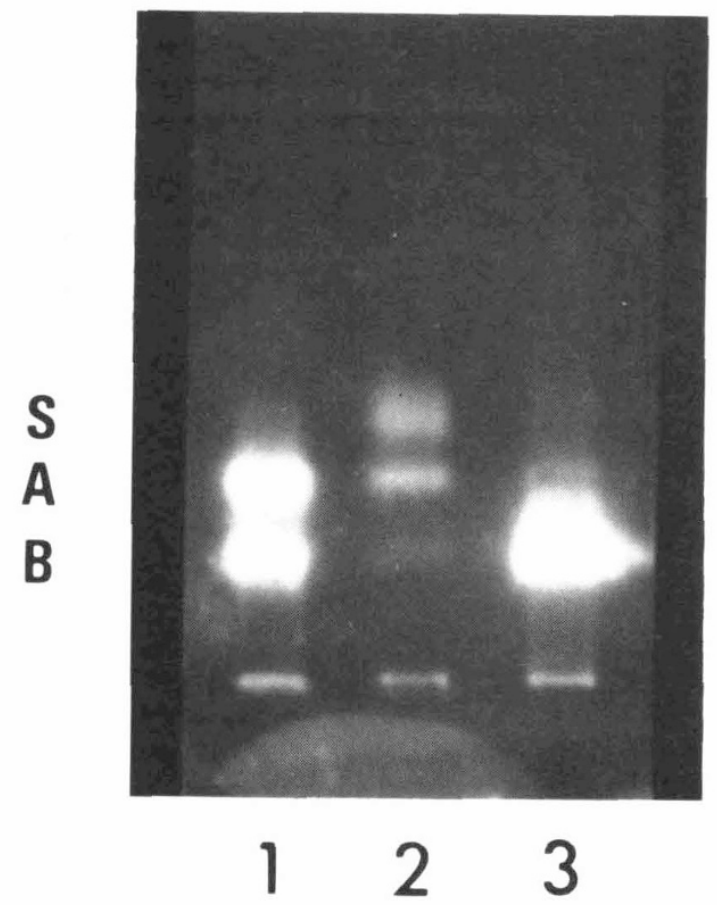

Fig. 1. Trophoblast hexosaminidase electrophoresis. 1 , normal; 2, Sandhoff disease; 3, Tay-Sachs disease.

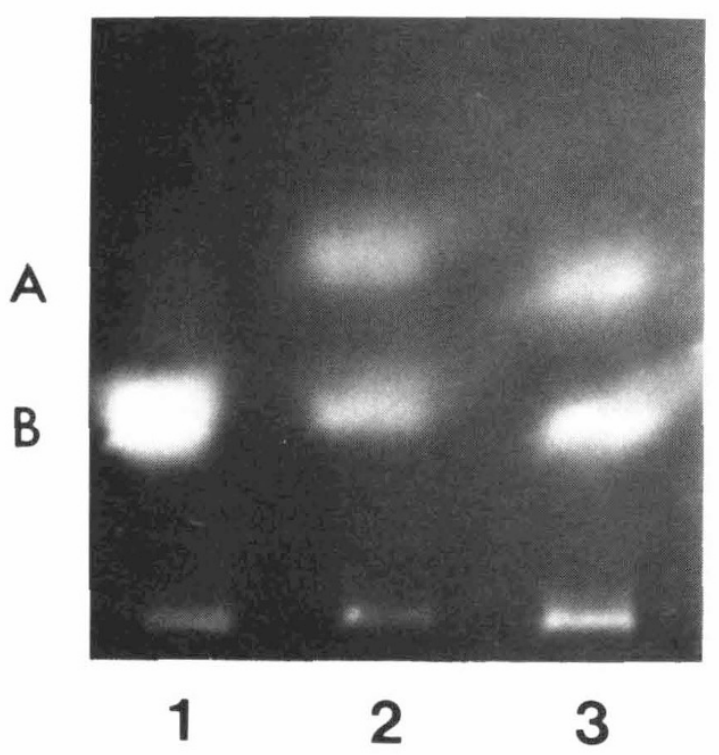

Fig. 2. Trophoblast arylsulfatase electrophoresis. 1, metachromatic leukodystrophy. 2 and 3 are normal.

Table 2. Placenta from affected fetuses*

\begin{tabular}{|c|c|c|c|c|c|}
\hline & $\begin{array}{c}\text { H. E. } \\
\text { (Pompe's } \\
\text { disease) }\end{array}$ & $\begin{array}{l}\text { G. A. (metachromatic } \\
\text { leukodystrophy) }\end{array}$ & $\begin{array}{l}\text { V. I. (Tay-Sachs } \\
\text { disease) }\end{array}$ & $\begin{array}{l}\text { D. U. (Sandhoff } \\
\text { disease) }\end{array}$ & $\begin{array}{c}\text { Control } \\
(\text { Sample 20) }\end{array}$ \\
\hline$\alpha$-Glucosidase, $\mathrm{pH} 4$ & $1.4 \dagger$ & 335 & & & $\begin{array}{c}325 \\
(125-620)\end{array}$ \\
\hline Arylsulfatase A & 104 & $1.1 \dagger$ & 40.5 & 104 & $\begin{array}{c}72 \\
(42-134)\end{array}$ \\
\hline Arylsulfatase B & & 86 & 97 & 110 & $\begin{array}{c}87 \\
(60-154)\end{array}$ \\
\hline$N$-Acetyl- $\beta$-glucosaminidase & 1690 & 2800 & $1280 \dagger$ & $122 \dagger$ & $\begin{array}{c}3.328 \\
(1200-6650)\end{array}$ \\
\hline
\end{tabular}

* Activity is expressed in $\mathrm{nmol} / \mathrm{mg}$ protein $/ \mathrm{h}$.

$\dagger$ Deficient enzyme. 
antenatal detection. First trimester prenatal diagnosis would reduce the waiting period by $6-8$ weeks, thus saving mothers the psychological strain of a long wait and the possible complications of a midtrimester therapeutic abortion. To evaluate the possibility of reliable diagnosis by trophoblast analysis several questions have to be answered. Is the quantity of tissue obtainable by biopsy sufficient for enzymatic tests? At 8-10 weeks of pregnancy, is the enzymatic level in trophoblasts high enough to permit reliable discrimination between a deficiency and a normal or a heterozygote level? Is the enzymatic phenotype of trophoblasts identical to that of amniotic cultured cells?

In our experience, 8 to $30 \mathrm{mg}$ of trophoblastic tissues is sufficient to provide an extract with optimal protein level (3-6 $\mathrm{mg} / \mathrm{ml}$ ) and to permit several assays and electrophoretic determinations. We have also found that the enzymatic level is higher than or similar to cultured amniotic cells except for $\alpha$-L-iduronidase and neuraminidase which show very low activities. Moreover, samples after dissection can be conserved at $-20^{\circ} \mathrm{C}$ for several days without loss of activity. In trophoblasts, we have evidence of detection of four deficiencies: acid $\alpha$-glucosidase, arylsulfatase $\mathrm{A}$, hexosaminidase $\mathrm{A}$, and hexosaminidases $\mathrm{A}$ and $\mathrm{B}$. The detection of other enzyme deficiencies is probably possible too. However, it remains to be seen whether Gaucher's disease and mucolipidosis type II or III would be possible candidates for this approach since some tissues (e.g. liver) cannot be used to detect these disorders by lysosomal enzyme detection with artificial substrate (1, 10, 11; our personal observations).

The use of natural substrate for Gaucher disease and the determination of $N$-acetylglucosaminyl-1-phosphotransferase in the case of mucolipidosis II and III might overcome eventual difficulties, but these techniques are available in very few laboratories. Complementary discussion about mucolipidosis prenatal diagnosis by lysosomal enzyme determination is reported in one of our papers (19).

One major problem which is not yet settled is that of the hazards of the technique. Up to now, our statistics include 34 biopsies. Three abortions have been observed. Two of them, however, showed confirmed chromosomal abnormalities and these pregnancies might have undergone spontaneous termination.

In conclusion, enzyme deficiency detection on trophoblasts obtained by biopsy represents an interesting new approach to early prenatal diagnosis of lysosomal disorders. From a practical point of view, in the case of total enzyme deficiency, abortion should be advised, but in other cases, until more experience is acquired, cultured amniotic cell analysis must also be performed in order to confirm the diagnosis.

Acknowledgments. We thank Miss Wetzel for typing the manuscript and Dr. Alan Strickland for his help in preparing the paper.

\section{REFERENCES}

1. Berman ER, Kohn G, Yatziv S, Stein H 1974 Acid hydrolase deficiency and abnormal glycoproteins in mucolipidosis III. Clin Chim Acta 52:115

2. Brambati B, Simoni G 1983 Diagnosis of fetal trisomy 21 in first trimester. Lancet 1:586

3. Butterworth J, Broadhead DM 1978 Acid $\beta$-glucosidase and the diagnosis of Gaucher's disease in liver and spleen. Clin Chim Acta 78:433

4. Dreyfus JC, Poenaru L 1975 Le diagnostic enzymatique dans les maladies lysosomiales. Arch Fr Pediatr 32:503

5. Dumez Y, Kaplan L, Gossens M, Poenaru L, Henrion R, Cedar L $1984 \mathrm{La}$ biopsie de trophoblaste nouvelle méthode de diagnostic antenatal. J Genet Hum, in press

6. Gosden JR, Mitchell AR, Gosden CM, Rodeck CH, Morsman JM 1982 Direct vision chorion biopsy and chromosome specific DNA probes for determination of fetal sex in first trimester prenatal diagnosis. Lancet 2:1416

7. Kaplan L, Dumez Y, Gossens M 1983 A method for fetal tissue sampling by chorion biopsy: a new approach to first trimester detection of abnormal glues. IRCS Med Sci 11:85

8. Kitagawa T, Owada M, Sakiyama T, Aoki K, Kamoshita S, Amenomori Y, Kobayashi T 1978 In utero diagnosis of Gaucher disease. Am J Hum Genet $30: 322$

9. Kazy Z, Rozovsky IS, Bakharev VA 1982 Chorion biopsy in early pregnancy: a method of early prenatal diagnosis for inherited disorders. Prenatal Diagn a me:39

10. Leroy JG, Ho MV, MacBrinn MC, Zielke K, Jacob K, O'Brien JS 1972 I cell disease: biochemical studies. Pediatr Res 6:752

11. Miller A 1978 I cell disease: isoelectric focusing, concanavalin A-Sepharose 4B binding and kinetic properties of human liver acid $\beta$-D-galactosidases. Biochim Biophys Acta 522:174

12. Milunsky A 1973 The Prenatal Diagnosis of Hereditary Disorders. Charles C Thomas, Springfield, IL

13. Nadler HL, Messina AM 1969 In utero detection of type II glycogenosis (Pompe's disease). Lancet 2:1277

14. Old JM, Ward RHT, Kragozly F, Petrou M, Modell B 1982 First trimester fetal diagnosis for haemoglobinopathies: three cases. Lancet 2:1413

15. Owada M, Sakiyama T, Kitagawa T 1977 Neuropathic Gaucher's disease with normal 4-methylumbelliferyl- $\beta$-glucosidase activity in liver. Pediatr Res $11: 641$

16. Poenaru L, Dreyfus JC 1973 Electrophoretic study of hexosaminidases. Hexosaminidase C Clin Chim Acta 43:439

17. Poenaru L, Dreyfus JC, Boué J, Nicolesco H, Ravise N, Bamberger J 1976 Prenatal diagnosis of fucosidosis. Clin Genet 10:260

18. Poenaru L, Girard S, Thepot F, Madelenat P, Huraux-Rendu C, Vinet MC, Dreyfus JC 1979 Antenatal diagnosis in three pregnancies at risk for mannosidosis. Clin Genet 16:428

19. Poenaru L, Castelnau L, Dumez Y, Thepot F 1984 First trimester prenatal diagnosis of mucolipidosis II (I cell diseases). Two affected fetuses. Am J Hum Genet, in press 